\title{
URBAN HYDROLOGY RESEARCH FUNDAMENTALS FOR WASTE MANAGEMENT PRACTICES
}

\author{
Kaur-Mikk Pehme ${ }^{1}$, Juris Burlakovs ${ }^{1,2,3}$, Mait Kriipsalu ${ }^{1,3}$, Jovita Pilecka ${ }^{4}$, Inga Grinfelde ${ }^{4}$, Toomas \\ Tamm $^{1}$, Yahya Jani², William Hogland ${ }^{2}$
}

${ }^{1}$ Estonian University of Life Sciences, Estonia

${ }^{2}$ Linnaeus University, Sweden

${ }^{3}$ University of Latvia, Latvia

${ }^{4}$ Latvia University of Life Sciences and Technologies, Latvia

juris@geo-it.lv

\begin{abstract}
The urbanization and increasing growth of planet's population accumulates significant volume of disposed waste as well as increases risks on human health and environmental safety. Landfill systems are the dynamic, living in space and time, potentially harmful entities that must be managed in as careful and smart way as possible. There are many studies related to landfill emissions such as leachates and methane. However, there is a need for advanced understanding of landfill hydrological regime and risks related to climate change and associated changes of hydrological cycle. The comprehensive studies about the urban hydrology are available; however, application to landfill management is fragmentary and inconsistent in several aspects. Landfill in long term has an impact on hydrological cycle. The heterogeneous land surface is one of aspects; however, there are still unanswered questions about the urban environment impact on water balance components. The aim of this study is to describe fundamentals of landfill hydrology in urban hydrological response unit context as well as evaluate the potential risks to environment and human health related to landfill geomorphology and hydrological balance in temporal climate conditions. The landfill hydrological cycle has similarities with urban hydrological cycle; however, there are additional components related to landfill specification, e.g., irrigation or leachate recirculation as well as total produced leachate.

Key words: urban hydrological response unit, solid waste, landfill water balance, Swedish Institute, biological degradation.
\end{abstract}

\section{Introduction}

The landfills are systems with mixed contaminants and approximate aftercare period from 200 till 500 years. During aftercare period there are risks to contaminate environment especially groundwater (Belevi \& Baccini, 1989). The landfills are identified as important source of groundwater contamination with organic and nonorganic pollutants (Fatta et al., 2002; Li et al., 2008; Alslaibi et al., 2011; Regadío et al., 2012; Li et al., 2014). The aquafer contamination with leachate is serious environmental issue not only in developing countries, for example Morocco (Smahi et al., 2013), Malaysia (Zawawia et al., 2012), India (Gunjan et al., 2012), but also in the USA where approximately $75 \%$ of the landfills have negative impact on groundwater quality (Jones-Lee \& Lee, 1993). Similar results are found in Denmark and other countries. As presented in Figure 1, there are 453 closed landfills in Latvia (LVGMC, 2019). Potential contamination risk is in 335 closed landfills as well as significant contamination is identified in 37 landfills. There is a need for advanced knowledge about

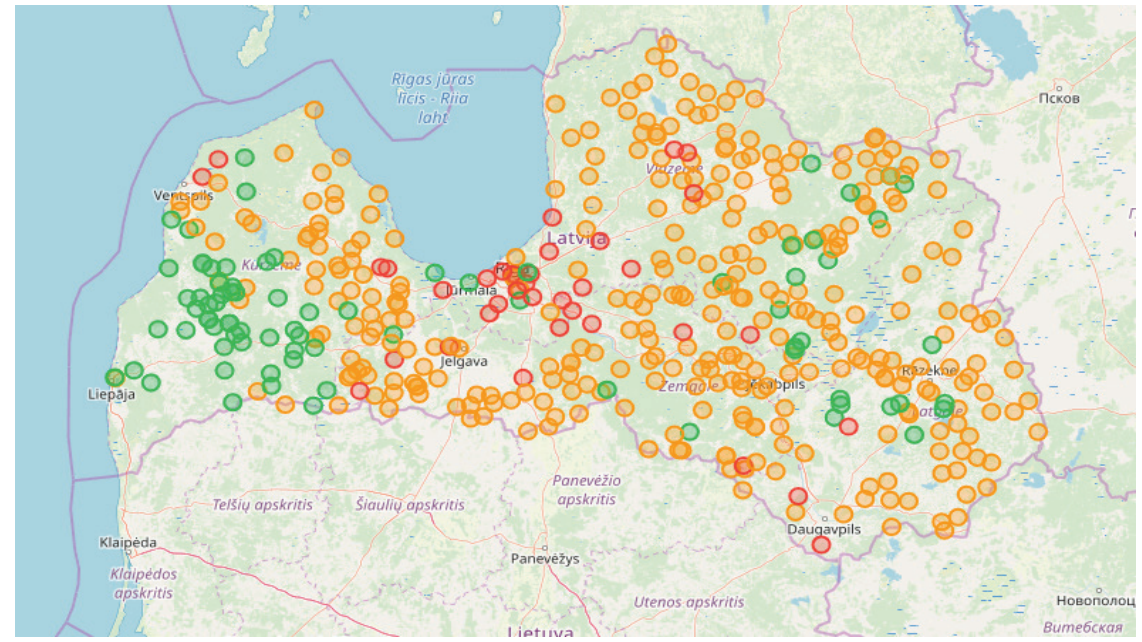

Figure 1. The location of closed landfills in Latvia where: red - contaminated site; yellow - potentially contaminated site; green - remediated site. 


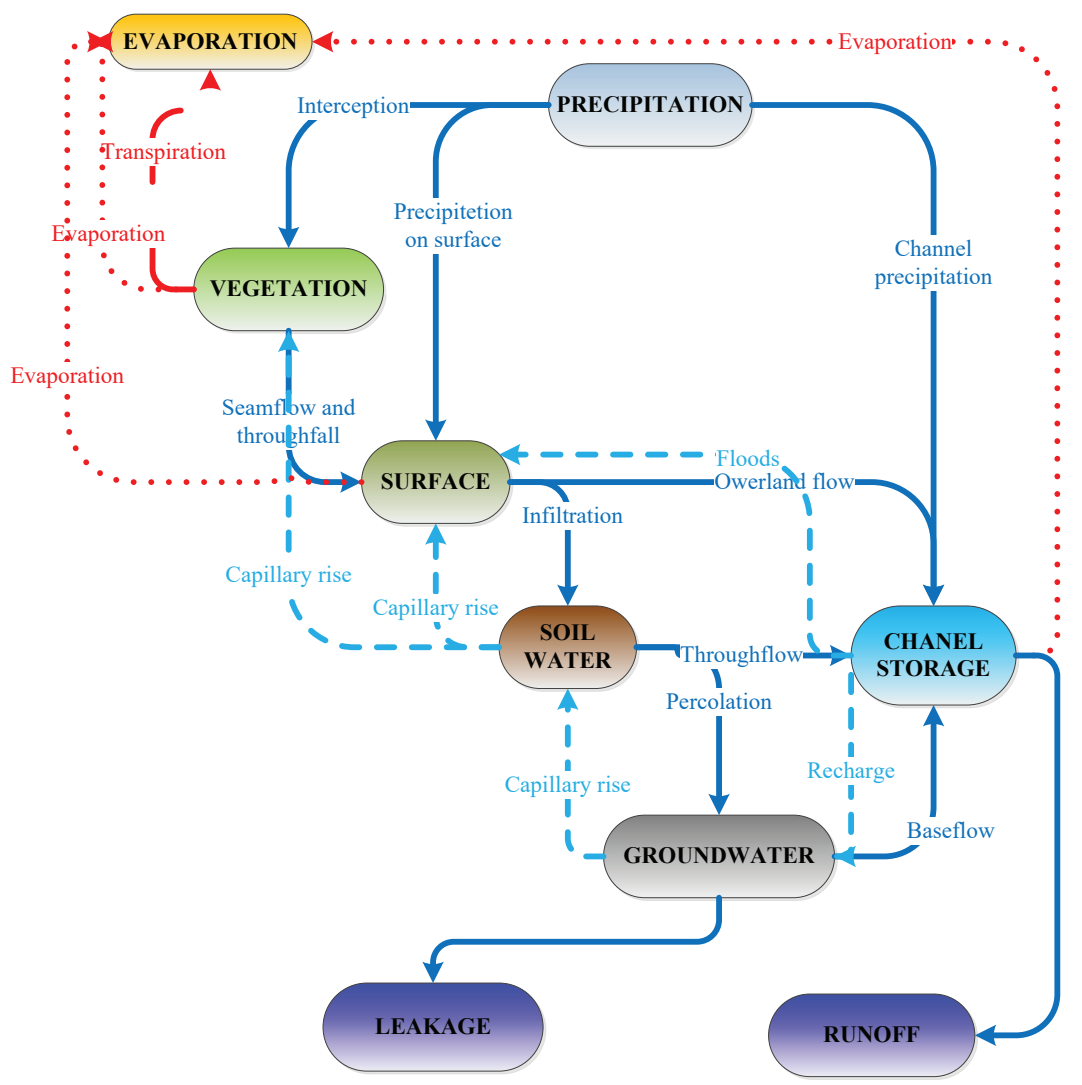

Figure 2. The hydrological cycle of natural catchment area (author courtesy according Ward \& Robinson, 2000).

landfill hydrology with the aim to develop and apply groundwater contamination mitigation measures and aquafers protection strategies.

Landfill as any urban environment changes hydrological regime and in long term has an impact on hydrological cycle. The heterogeneous land surface changes hydrological regime and impacts a hydrological cycle, but there are still unanswered questions about the urban environment impact on water balance components (Van de Ven, 1990). In the natural hydrological cycle, there are three general components (Figure 2) such as precipitations, evapotranspiration and run-off which are influenced by interception, infiltration, geomorphology, velocity etc.

The urban hydrological cycle has some components, but they are modified (Figure 3). To evaluate water balance in urbanized catchment area, proportion of waterproof surface is used (Carle et al., 2005, 2008; Zhou et al., 2010; Mitchell et al., 2003; Lhomme et al., 2004; Ogden et al., 2011; Xiao et al., 2007). The precipitation is one of the main components of hydrological cycle and the impact of urban environment on precipitation is investigated in some studies (Taha, 1997; Shepherd et al., 2002; Shepherd, 2006) and the main conclusion is that urbanization impact on precipitation is with a local effect. There is strong evidence of urbanization impact on evapotranspiration. However, there is a need for additional studies (Cheng et al., 2011). Due to lack of vegetation in urban areas, the total evapotranspiration is lower than in rural areas (Taha, 1997; Chen et al., 2009). The vegetation in urban environment has a larger spatial diversity and there is a need for new technologies and modelling approaches to investigate this phenomenon. The water retention in natural areas is in the range from 0.5 to $15 \mathrm{~mm}$. However, in urban areas water retention is from $0.2 \mathrm{~mm}$ to $3.2 \mathrm{~mm}$ (Marsalek et al., 2007). The main indicator of hydrological balance change is roughness of surface, and it is one of the main research objects in hydrological analysis (Arnold \& Gibbons, 1996; Shuster et al., 2005; Zhou et al., 2010; Jacobson, 2011). The rain water and waste water collection are components of urban hydrological cycle and are developed to protect urban areas from floods and provide safe environment for humans (Delleur, 2003; Egodawatta et al., 2013). The impact of urbanization on groundwater levels is investigated in many studies (Appleyard 1995; Changming et al., 2001; Schirmer et al., 2012). In the urbanized environment the natural recharge of groundwater is transformed in new forms (Foster, 1990): 1) waterproof surfaces disturb direct groundwater recharge and deplete groundwater resources; 2) the urbanization increases 


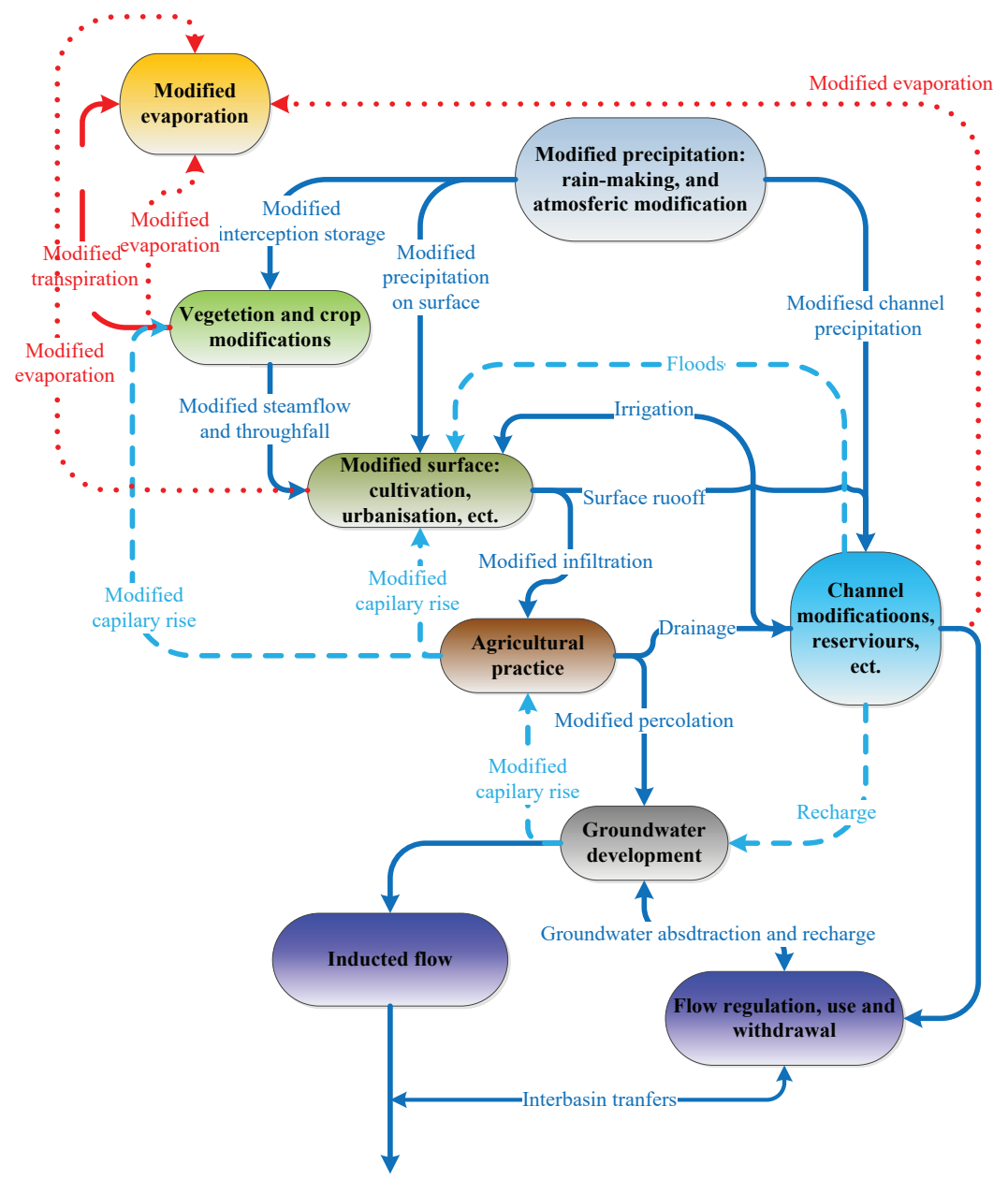

Figure 3. The hydrological cycle of urban catchment area (Ward \& Robinson, 2000).

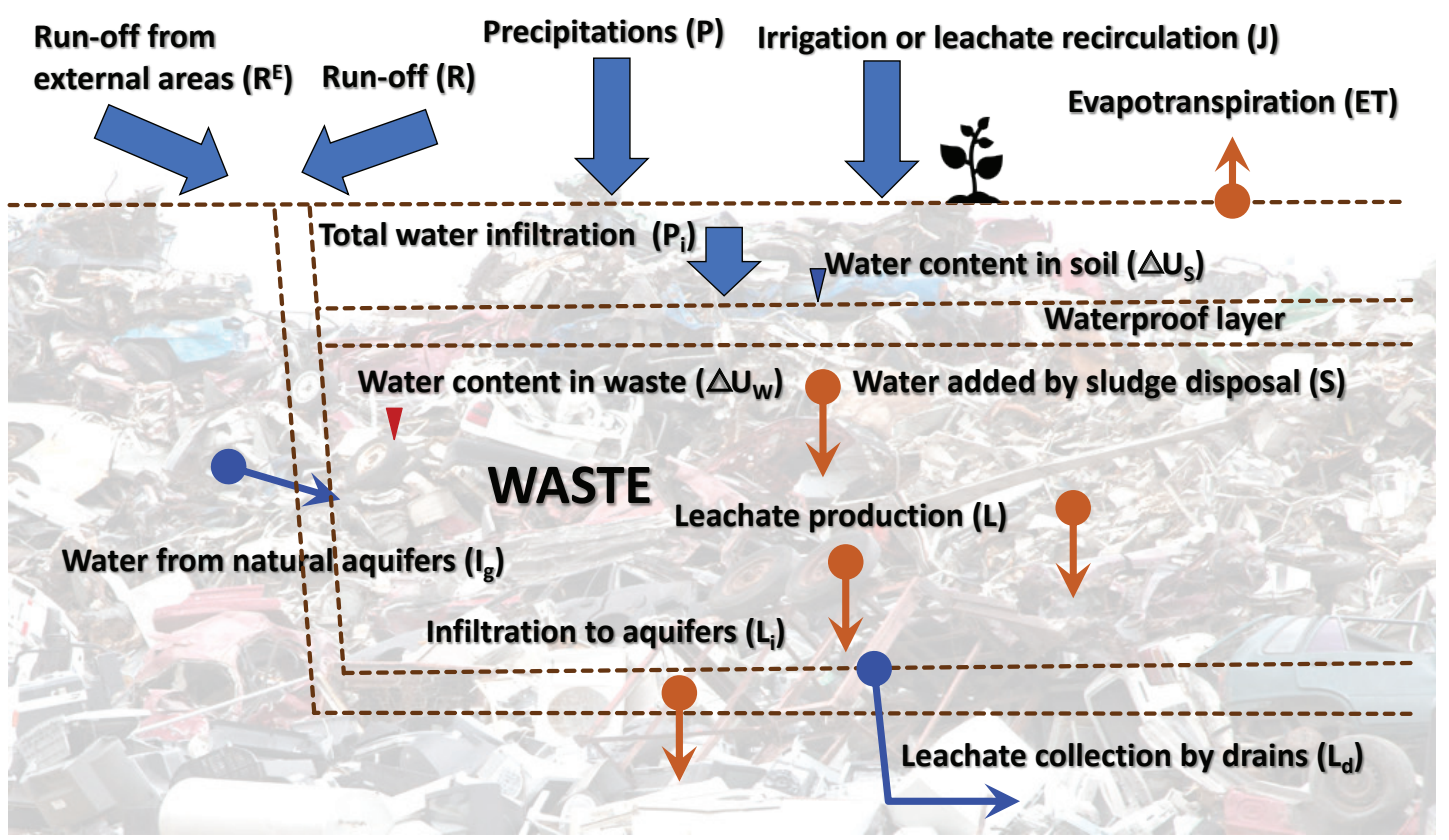

Figure 4. Landfill hydrological cycle conceptual scheme. 
groundwater recharge associated with infiltration from anthropogenic systems (Lerner, 2002). In urbanized areas, the land surface is covered by waterproof surfaces where infiltration is close to zero (Leopold, 1968). The proportion of waterproof surfaces variates from $50 \%$ in residential areas to $90 \%$ in industrial areas (Foster, 1990). The aim of this study is to describe fundamentals of landfill hydrology in urban hydrological response unit context as well as evaluate the potential risks to environment and human health related to landfill geomorphology and hydrological balance in temporal climate conditions. The main tasks are: first, to investigate and describe water balance in landfills, second, divide environmental risk groups according to landfill geomorphology and hydrological balance, hydrological cycle components by landfill groups.

\section{Materials and Methods}

Landfill conceptual hydrological cycle is presented in Figure 4. The precipitation $(\mathrm{P})$ is the same as in urban and natural areas. Additionally to precipitations, there is water of irrigation or leachate recirculation (J). The evapotranspiration (ET) in landfill is related to vegetation and mostly landfill areas are covered by grass and in some cases covered by bushes and even trees. Surface run-off (R) in landfill area is lower than in urban areas but higher than in natural areas. Run-off from external areas $\left(\mathrm{R}^{\mathrm{E}}\right)$ is not acceptable but in some cases can be issued by geomorphological conditions. The water content in soil $\left(\mathrm{U}_{\mathrm{S}}\right)$ is part of water balance equation 1:

$$
\mathrm{Pi}=\mathrm{P}+\mathrm{J}+\mathrm{R}^{\mathrm{E}}-\mathrm{R}-\mathrm{ET} \pm \Delta \mathrm{U}_{\mathrm{S}}
$$

Where: Pi - water infiltrated in waste $(\mathrm{mm})$; $\mathrm{P}-$ precipitation $(\mathrm{mm}) ; \mathrm{J}$ - water of irrigation or leachate recirculation $(\mathrm{mm}) ; \mathrm{R}^{\mathrm{E}}-$ Run-off from external areas (mm); R-Surface run-off (mm); ET evapotranspiration $(\mathrm{mm}) ; \mathrm{U}_{\mathrm{S}}$ water content in soil $(\mathrm{mm})$.

Landfill hydrological balance has additional components: water added by sludge disposal (S), water production or consumption by biological degradation of organic matter (b), total leachate production (L) see equation 2 :

$$
\mathrm{L}=\mathrm{Pi}+\mathrm{S}+\operatorname{Ig} \pm \Delta \mathrm{U}_{\mathrm{w}}+\mathrm{b}
$$

Where: $\mathrm{L}$ - total leachate production $(\mathrm{mm}) ; \mathrm{S}$ - water added by sludge disposal $(\mathrm{mm})$; Ig - water from natural aquifers; $\mathrm{U}_{\mathrm{W}}$ - water content in waste $(\mathrm{mm})$; $\mathrm{b}$ - water production or consumption by biological degradation of organic matter.

Water content in waste is related to waste source and climate condition during waste disposal. The landfill water balance components such as water infiltration from natural aquifers, external run-off and leachate infiltration in natural aquifers are critical components of landfill water balance related to environmental risks.

\section{Results and Discussion}

The potential risks to human health and environment are related to leachate infiltration in aquifers. The landfills in Latvia were divided in three groups by landfill conditions and developed conceptual hydrological balance for each of groups using available information accessible in Latvia State Forest geographical information systems (LVM, 2019). The first group is landfills with controlled area and low risk of leachate infiltration in natural aquifers as presented in Figure 5.

The second group of landfills is closed and recovered, but the soil layer is associated with medium environmental risks (Figure 6). There is lack of surface run-off collection system as well as identified

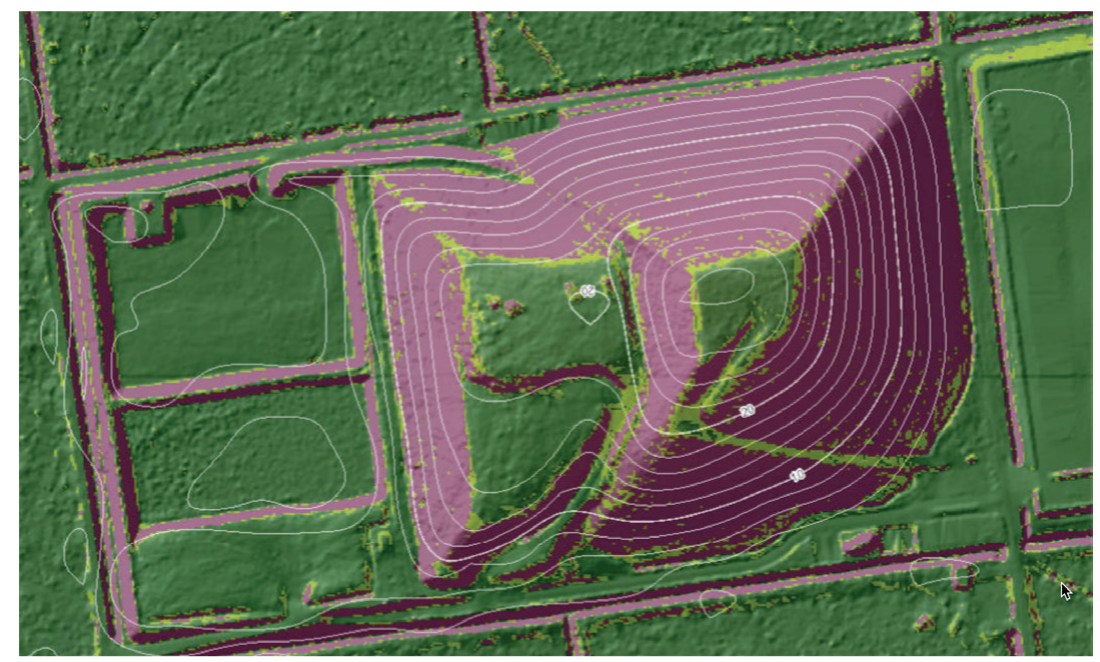

Figure 5. Landfill with low environmental risks. 


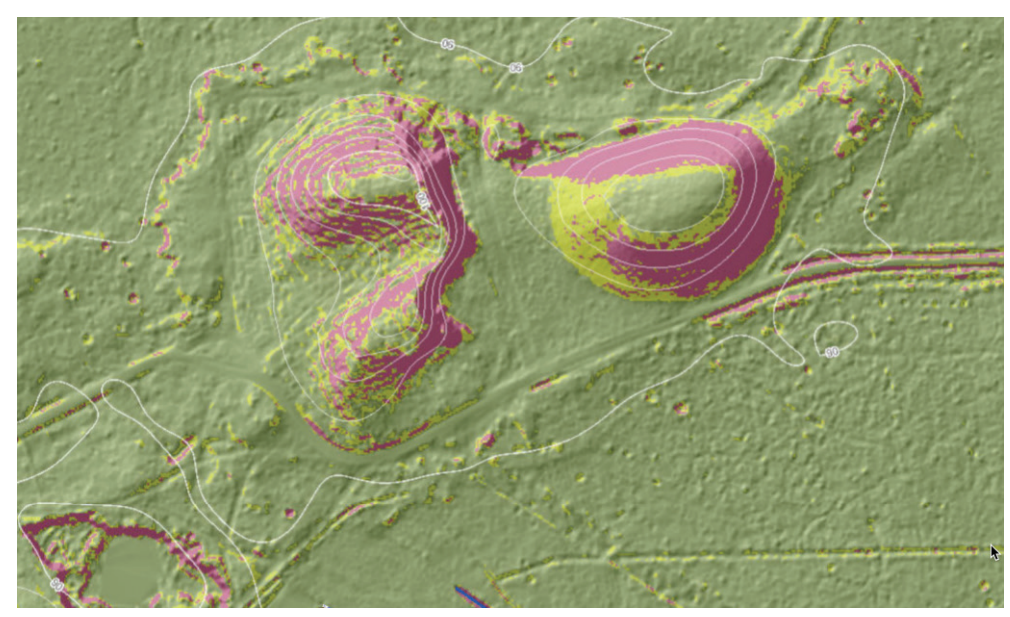

Figure 6. Landfill with medium environmental risks.

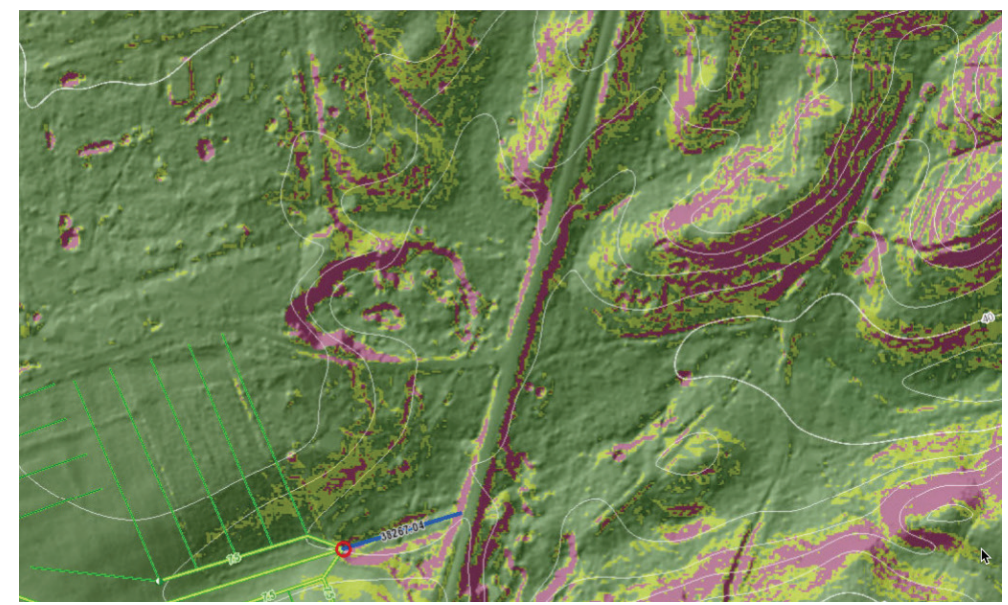

Figure 7. Landfill with high environmental risks.

Table 1

The hydrological cycle components by landfill group

\begin{tabular}{|l|r|r|r|}
\hline \multicolumn{1}{|c|}{ Component of landfill hydrological balance } & $\begin{array}{c}\text { Low risk } \\
\text { group }\end{array}$ & $\begin{array}{c}\text { Medium risk } \\
\text { group }\end{array}$ & $\begin{array}{c}\text { High risk } \\
\text { group }\end{array}$ \\
\hline Water of irrigation or leachate recirculation $(\mathrm{J})$ & $\mathrm{J} \geq 0$ & $\mathrm{~J}=0$ & $\mathrm{~J}=0$ \\
\hline Run-off from external areas $\left(\mathrm{R}^{\mathrm{E}}\right)$ & $\mathrm{R}^{\mathrm{E}} \leq 0$ & $\mathrm{R}^{\mathrm{E}}=0$ & $\mathrm{R}^{\mathrm{E}}>0$ \\
\hline Water infiltrated in waste $(\mathrm{Pi})$ & $\mathrm{Pi}=0$ & $\mathrm{Pi}=0$ & $\mathrm{Pi}>0$ \\
\hline Water from natural aquifers $(\mathrm{Ig})$ & $\mathrm{Ig}=0$ & $\mathrm{Ig} \geq$ & $\mathrm{Ig}>0$ \\
\hline Leachate infiltrated in natural aquifers $(\mathrm{Li})$ & $\mathrm{Li}=0$ & $\mathrm{Li}>0$ & $\mathrm{Li}>0$ \\
\hline Leachate collected by drainage system $(\mathrm{Ld})$ & $\mathrm{Ld}>0$ & $\mathrm{Ld}=0$ & $\mathrm{Ld}=0$ \\
\hline Water added by sludge disposal $(\mathrm{S})$ & $\mathrm{S} \geq 0$ & $\mathrm{~S}=0$ & $\mathrm{~S}=0$ \\
\hline
\end{tabular}

risks related to water infiltration in waste from natural aquifers and leachate infiltration into natural aquifers.

The third group of landfills has high environmental risks and includes landfills developed in abandoned sand or gravel mining areas where run-off is not collected and additional run-off from external areas infiltrates in waste body. This type of landfills is characterized with small amount of waste, but high risks of leachate infiltration in natural aquifers.

The analysis of hydrological components by groups is presented in Table 1. Low risk group of landfills has a leachate recirculation system. The water exchange between waste body and natural aquafers is close to 0 . The clean run-off water from landfill 
is collected and delivered to the closest water body. In the medium risk group of landfills, there is probability of water exchange between waste body and natural aquafers, but normally it is close to zero. The risks of environment contamination are related to leachate generated by biological degradation of organic matter.

The high environmental risk group of landfills is characterized by positive external run-off, positive infiltration from natural aquifers and leachate infiltration in natural aquifers where contamination migrates to the closest water body and is transported to the Baltic Sea.

\section{Conclusions}

The landfill hydrological cycle has similarities with an urban hydrological cycle; however, there are additional components of hydrological cycle components related to landfill specification, such as water of irrigation or leachate recirculation and total produced leachate.

There are medium or high environmental risks related to closed landfills, and there is a need for additional investigation using GIS and hydrological modelling tools to mitigate contamination of groundwater and deep aquifers.

More studies are needed and modelling elaborated in order to diminish the discharges of contaminated groundwater and greenhouse gasses out of urban areas including contaminated and potentially contaminated sites and landfills.

\section{Acknowledgements}

This study was supported by the Swedish Institute sponsored LASUWAMA initiative. Authors acknowledge Interreg South Baltic project 'Reviving Baltic Resilience' and Geo IT Ltd. on experience and knowledge exchange. Also, nationally funded grant 'The implementation of the circular economy principles on utilisation of previously deposited waste as resources and energy; and the use of stabilized fine fraction as methane degradation layer to minimise emissions of greenhouse gases' (Estonian University of Life Sciences) are acknowledged. COST Action CA15115 Mining the European Anthroposphere (MINEA) is acknowledged for providing grounds for networking and Eesti Maaülikooli ASTRA projekt Väärtusahelapõhine biomajandus as dissemination entity.

\section{References}

1. Alslaibi, T.M., Mogheir, Y.K., \& Afifi, S. (2011). Assessment of groundwater quality due to municipal solid waste landfill leachate. J. Environ. Sci. Technol., 4, 419-536. DOI: 10.3923/jest.2011.419.436.

2. Appleyard, S. (1995). The impact of urban development on recharge and groundwater quality in a coastal aquifer near Perth, Western Australia. Hydrogeology Journal, 3 (2), 65-75. DOI: 10.1007/s100400050072.

3. Arnold, C.L., \& Gibbons, C.J. (1996). Impervious surface coverage - the emergence of a key environmental indicator. J. Am. Plan. Assoc., 62 (2), 243-258. DOI: 10.1080/01944369608975688.

4. Belevi, H., \& Baccini, P. (1989). Long-term behaviour of municipal solid waste landfills. Waste Management \& Research, 7, 43-56. DOI: 10.1177/0734242X8900700106.

5. Chen, J., Arleen, A.H., \& Lensyl, D.U. (2009). A GIS-based model for flood inundation. J. Hydrology, 373 (1-2), 184-192. DOI: 10.1016/j.jhydrol.2009.04.021.

6. Carle, M.V., Halpin, P.N., \& Stow, C.A. (2005). Patterns of watershed urbanization and impacts on water quality. J. Am. Plan. Assoc., 41 (3), 693-708. DOI: 10.1111/j.1752-1688.2005.tb03764.x.

7. Changming, L., Jingjie, Y., \& Kendy, E. (2001). Groundwater exploitation and its impact on the environment in the north China plain. Water International, 26 (2), 265-272. DOI: 10.1080/02508060108686913.

8. Cheng, L., Zongxue, X., Wang, D., \& Cai, X. (2011). Assessing interannual variability of evapotranspiration at the catchment scale using satellite-based evapotranspiration data sets. Water Resources Research, 47 (9). DOI: $10.1029 / 2011$ WR010636.

9. Delleur, J.W. (2003). The evolution of urban hydrology: past, present, future. Journal of Hydraulic Engineering, 129 (8), 563-573. DOI: 10.1061/(ASCE)0733-9429(2003)129:8(563)

10. Egodawatta, P., Ziyath, A., \& Goonetilleke, A. (2013). Characterizing metal build-up on urban road surfaces. Environmental Pollution, 176, 87-91. DOI: 10.1016/j.envpol.2013.01.021.

11. Fatta, D., Naoum, D., \& Loizidou, M. (2002). Integrated environmental monitoring and simulation system for use as a management decision support tool in urban areas. Journal of Environmental Management, 64, 333-343. DOI: 10.1006/jema.2001.0485.

12. Foster, S.S.D. (1990). Impacts of urbanization on groundwater. In: Hydrological Processes and Water Management in Urban Areas (ed. by H. Massing, J. Packman \& F. Zuidema) (Papers from UrbanWater'88 Symposium at Duisburg, Germany, April 1988), 187-207. IAHS Publ. No. 198.

13. Gunjan, B., Swamee, P.K., Arvind, K., \& Bansal, A. (2012). Assessment of groundwater quality near municipal solid waste landfill by an Aggregate Index Method. International Journal of Environmental Sciences, 2 (2), 1492-1503. DOI: 10.6088/ijes.00202030034. 
14. Jacobson, C.R. (2011). Identification and quantification of the hydrological impacts of imperviousness in urban catchments: a review. Journal of Environmental Management, 92 (6), 1438-1448. DOI: 10.1016/j. jenvman.2011.01.018.

15. Jones-Lee, A., \& Lee, G.F. (1993). Groundwater Pollution by Municipal Landfills: Leachate Composition, Detection and Water Quality Significance. Proc. Sardinia '93IV International Landfill Symposium, Sardinia, Italy, pp. 109-1103.

16. Leopold, L.B. (1968). Hydrology for Urban Land Planning - A guidebook on the Hydrologic Effects of urban Land Use. U.S. Government Printing Office, Washington.

17. Lerner, D.N. (2002). Identifying and quantifying urban recharge: a review. Hydrogeology Journal, 10 (1), 143-152. DOI: 10.1007/s10040-001-0177-1.

18. Lhomme, J., Bouvier, C., Perrin, J.-L. (2004). Applying a GIS-based geomorphological routing model in urban catchments. Hydrogeology Journal, 299 (3-4), 203-216. DOI: 10.1016/j.jhydrol.2004.08.006.

19. Li, C.P., Li, G.X., Luo, Y.M., \& Li, Y.F. (2008). Fuzzy mathematics-based groundwater quality evaluation of six MSW landfills in Beijing. Journal of Environmental Sciences, 29, 2729-2735.

20. Li, Y., Li, J.H., \& Deng, C. (2014). Occurrence, characteristics and leakage of polybrominated diphenyl ethers in leachate from municipal solid waste landfills in China. Environmental Pollution, 184, 94-100. DOI: 10.1016/j.envpol.2013.08.027.

21. LVGMC (2019). Piesārṇoto un potenciāli piesārṇoto vietu karte (Map of contaminated and potentially contaminated sites). Retrieved February 20, 2019, from https://www.meteo.lv/lapas/vide/piesarnoto-unpotenciali-piesarnoto-vietu-registrs/piesarnoto-un-potenciali-piesarnoto-vietu-registrs?id=1527\&nid=37. (in Latvian)

22. LVM (2019). LVM GEO G̦eotelpiskās informācijas tehnologijas (LVM GEO Geospatial Information Technologies). Retrieved February 20, 2019, from https://www.lvmgeo.lv/kartes. (in Latvian)

23. Marsalek, J., Jiménez-Cisneros, B., Karamouz, M., Malmquist, P.-A., Goldenfum, J., \& Chocat, B. (2007). Urban Water Cycle Processes and Interactions: Urban Water Series - UNESCO-IHP. Springer, Berlin.

24. Mitchell, V.G., McMahon, T.A., \& Mein, R.G. (2003). Components of the total water balance of an urban catchment. Environmental Management, 32 (6), 735-746. DOI: 10.1007/s00267-003-2062-2.

25. Ogden, F.L., Pradhan, N.R., Downer, C.W., \& Zahner, J.A. (2011). Relative importance of impervious area, drainage density, width function, and subsurface storm drainage on flood runoff from an urbanized catchment. Water Resources, 47 (12), W12503.

26. Regadío, M., Ruiz, A.I., Soto, I.S., Rastrero, M.R., Sánchez, N., Gismera, M.J., Sevilla, M.T., Silva, da P., Procopio, J.R., \& Cuevas, J. (2012). Pollution profiles and physicochemical parameters in old uncontrolled landfills. Waste Management, 32, 482-497. DOI: 10.1016/j.wasman.2011.11.008.

27. Schirmer, M., Leschik, S., \& Musolff, A. (2012). Current research in urban hydrogeology - a review. Advances in Water Resources, 51, 280-291. DOI: 10.1016/j.advwatres.2012.06.015.

28. Shepherd, J.M. (2006). Evidence of urban-induced precipitation variability in arid climate regimes. Journal of Arid Environments, 67 (4), 607-628. DOI: 10.1016/j.jaridenv.2006.03.022.

29. Shepherd, J.M., Pierce, H., \& Negri, A.J. (2002). Rainfall modification by major urban areas: observations from space borne rain radar on the TRMM satellite. Journal of Applied Meteorology and Climatology, 41 (7), 689-701. DOI: 10.1175/1520-0450(2004)043<0941:CORMBM>2.0.CO;2.

30. Shuster, W.D., Bonta, J., Thurston, H., Warnemuende, E., \& Smith, D.R. (2005). Impacts of impervious surface on watershed hydrology: a review. Urban Water Journal, 2 (4), 263-275. DOI: 10.1080/15730620500386529.

31. Smahi, D., Hammoumi, O.E., \& Fekri, A. (2013). Assessment of the impact of the landfill on groundwater quality: a case study of the Mediounasite, Casablanca, Morocco. Journal of Water Resource and Protection, 5, 440-445. DOI: 10.4236/jwarp.2013.54043.

32. Taha, H. (1997). Urban climates and heat islands: albedo, evapotranspiration, and anthropogenic heat. Energy Build., 25 (2), 99-103. DOI: 10.1016/S0378-7788(96)00999-1.

33. Van de Ven, F.H.M. (1990). Water Balances of Urban Areas. Hydrological Processes and Water Management in Urban Areas, 198. IAHS Publication, 21-32.

34. Ward, R.C., \& Robinson, M. (2000). Principles of Hydrology. London: McGraw-Hill Publishing Company. $450 \mathrm{p}$.

35. Xiao, Q., McPherson, E.G., Simpson, J.R., \& Ustin, S.L. (2007). Hydrologic processes at the urban residential scale. Hydrological Processes, 21, 2174-2188. DOI: 10.1002/hyp.6482. 
36. Zawawia, M.H., Syafalnia Abustan, I., \& Nazria, M.A.A. (2012). Assessment of hydrochemical and isotopic characteristics at Matang Landfill Site using multivariate analysis. Procedia Engineering, 50, 333-342. DOI: 10.1016/j.proeng.2012.10.038.

37. Zhou, Y., Wang, Y., Gold, A.J., \& August, P.V. (2010). Modeling watershed rainfall-runoff relations using impervious surface-area data with high spatial resolution. Hydrogeology Journal, 18 (6), 1413-1423. DOI: 10.1007/s10040-010-0618-9. 